\title{
Mesenchymal stem cell transplantation after acute myocardial infarction: a meta-analysis of clinical trials
}

\author{
Armin Attar ${ }^{{ }^{*}} \mathbb{D}$, Fateme Bahmanzadegan Jahromi ${ }^{2}$, Shahin Kavousi ${ }^{2}$, Ahmad Monabati $^{3,4}$ and Asma Kazemi ${ }^{5^{*}}$
}

\begin{abstract}
Background: Trials investigating the role of mesenchymal stem cells (MSCs) in increasing ejection fraction (LVEF) after acute myocardial infarction (AMI) have raised some controversies. This study was conducted to find whether transplantation of MSCs after AMI can help improve myocardial performance indices or clinical outcomes.

Methods: Randomized trials which evaluated transplantation of MSCs after AMI were enrolled. The primary outcome was LVEF change. We also assessed the role of cell origin, cell number, transplantation time interval after AMI, and route of cell delivery on the primary outcome.

Results: Thirteen trials including 956 patients (468 and 488 in the intervention and control arms) were enrolled. After excluding the biased data, LVEF was significantly increased compared to the baseline among those who received MSC (WMD $=3.78 \%, 95 \% \mathrm{Cl}: 2.14$ to $\left.5.42, p<0.001, P^{2}=90.2 \%\right)$ with more pronounced effect if the transplantation occurred within the first week after $\mathrm{AMI}\left(\mathrm{MD}=5.74 \%, 95 \% \mathrm{Cl}: 4.297\right.$ to $\left.7.183 ; l^{2}=79.2 \% p<0.001\right)$. The efficacy of transendocardial injection was similar to that of intracoronary infusion ( $4 \%$ [ $95 \% \mathrm{Cl}: 2.741$ to $5.259, p<0.001]$ vs. $3.565 \%$ [95\%Cl: 1.912 to $5.218, p<0.001$, respectively). MSC doses of lower and higher than $10^{7}$ cells did not improve LVEF differently (5.24\% [95\%Cl: 2.06 to 8.82, $p=0.001$ ] vs. 3.19\% [95\%Cl: 0.17 to $6.12, p=0.04$ ], respectively).

Conclusion: Transplantation of MSCs after AMI significantly increases LVEF, showing a higher efficacy if done in the first week. Further clinical studies should be conducted to investigate long-term clinical outcomes such as heart failure and cardiovascular mortality.
\end{abstract}

Keywords: Meta-analysis, Mesenchymal, Stem cell, Myocardial infarction

\section{Background}

Myocardial infarction (MI), a common presentation of coronary artery disease, is the main cause of death in the developed countries [1]. Over the past few decades, a rise in the incidence of heart failure (HF) was observed

\footnotetext{
*Correspondence: attarar@sums.ac.ir; attar_armin@yahoo.com; Kazemiasma66@gmail.com

${ }^{1}$ Department of Cardiovascular Medicine, TAHA Clinical Trial Group, School of Medicine, Shiraz University of Medical Sciences, Zand Street, Shiraz, Iran

${ }^{5}$ Nutrition Research Center, Shiraz University of Medical Sciences, PO Box 71645-111, Shiraz, Iran

Full list of author information is available at the end of the article
}

in contrast to the reduction in the mortality rate after MI [2]. In spite of the current guideline-directed therapy [3], mortality and morbidity of post-MI heart failure are quite high [4]. Although the current managements for HF are prolonging the patients' life while improving their symptoms, they do not restore the normal histologic architecture and induce regeneration in the damaged cells. Therefore, improving confirmed treatments and developing further approaches to treat patients with post-MI heart failure are strongly required [5].

One approach to restore the damaged myocardium after MI has pointed at stem cell-based therapies [6]. Cell therapy was initially proposed a putative approach original author(s) and the source, provide a link to the Creative Commons licence, and indicate if changes were made. The images or other third party material in this article are included in the article's Creative Commons licence, unless indicated otherwise in a credit line to the material. If material is not included in the article's Creative Commons licence and your intended use is not permitted by statutory regulation or exceeds the permitted use, you will need to obtain permission directly from the copyright holder. To view a copy of this licence, visit http://creativecommons.org/licenses/by/4.0/. The Creative Commons Public Domain Dedication waiver (http://creativeco mmons.org/publicdomain/zero/1.0/) applies to the data made available in this article, unless otherwise stated in a credit line to the data. 
to reconstruct the damaged myocardium. Cell therapy moved forward to human studies with outstanding speed, using skeletal myoblasts in patients with HF in 2001 [7], and BM-derived mononuclear cell (BMMNC) transplantation in acute MI in 2002 [8]. Since then, many studies on animals and humans have been performed to assess different cell types and their ability to repair cardiac and vascular damage in the settings of MI, cardiomyopathy, etc. Most of the studies on cell therapy in AMI are done by BM-MNCs. Based on a meta-analysis by Fisher and colleagues, treatment with BM-MNC would increase LVEF after AMI by $2.72 \%$ [9]. However, studies on the mesenchymal stem cells (MSC)s are more encouraging. In the TAC-HFT trial, it was shown that MSC was about twice as much effective as the bone marrow-derived mononuclear cells (BM-MNCs) [10].

Mesenchymal stem cells (MSCs) are a population of cells initially isolated from the BM and have been found in other organs and tissues such as Wharton's jelly and adipose tissue [11]. The International Society for Cellular therapy describes Mesenchymal stem cells (MSCs) as a population of cells that adheres to plastic in standard culture conditions, expresses CD73, CD90, and CD105 in the absence of CD34, CD45, HLA-DR, CD14 or CD11b, CD79a, or CD19 surface molecules, and has the ability to differentiate into osteoblasts, adipocytes, and chondroblasts in vitro [12]. Due to the availability of these resources, these tissues are becoming the dominant source for isolation of MSC for clinical uses [13]. Furthermore, the safety of MSCstherapy from these origins has been confirmed previously [13]. Because of their desirable features, such as an easily accessible source of adult stem cell with multi-lineage potential, simplicity of isolation from bone marrow and expansion, maintenance of stem cell niches, potential of allogeneic transplant, recruitment of endogenous stem cells, and secretion of paracrine factors, MSCs are progressively used in clinical trials of stem cell therapy [14]. Clinical trials using MSCs in AMI are controversial but encouraging. Some have shown promising results while others have been neutral. In addition, most of them are conducted by a low sample volume. Furthermore, many questions such as the optimal number of stem cells that must be injected and the optimal time course of delivery to maximize recovery of cardiac function post-infarct remain to be answered. Consequently, performing a meta-analysis seemed essential to reveal the real effect of these cells, so this study aimed to investigate the effect of MSC on the cardiac function after AMI and factors affecting it by conducting a meta-analysis.

\section{Method}

The Preferred Reporting Items for Systematic reviews and Meta-Analyses (PRISMA) statement (http://www. prisma-statement.org/) was used in this systematic review. The PICOS (participants, intervention, comparison, and outcomes of study design) model was used to formulate the study question.

\section{Search strategy and study selection criteria}

Relevant studies were identified by searching PubMed, Scopus, the Cochrane Library (to April 2021), Embase, Pubmed, Google Scholar, and clinicaltials.gov without language limit. The search terms used included infarction, ischemia, ischemic disease and cardiac, heart, myocardial and mesenchymal stem cell, progenitor, stromal cell, multipotent stromal cell, alone or in combination with each other.

All clinical trials (randomized or non-randomized) which had investigated the effects of stem cell therapy on myocardial function in patients with acute myocardial infarction were eligible to be included in the metaanalysis. Two reviewers independently screened the eligibility of studies. Any discrepancies were resolved by discussion with a third author.

\section{Risk of bias (quality) assessment}

Two authors independently assessed the quality of the studies using Cochrane Risk of Bias Tool for Randomized Controlled Trials; the studies were assessed for criteria such as random sequence generation, allocation concealment, blinding of participants, personnel and outcome assessment, incomplete outcome data, and selective reporting. In cases all the criteria were met, or only had one criterion rated unclear, the quality was judged as good. When one criterion was met or two criteria were unclear, the article was graded as fair quality; in case two or more criteria were not met or unclear, the article was considered to be of poor quality. Any disagreement was resolved by discussion.

\section{Data extraction}

Data extraction was carried out independently by two reviewers. The accuracy of the extracted data was checked by a third reviewer. If the included studies did not provide the required data, we requested the necessary data from corresponding authors. The extracted data included authors, year of publication, manuscript type, study design, cell origin, cell number, route of delivery, number of participants, age, sex, measurement tool, primary intervention, transplantation time after MI, follow-up, diabetes mellitus (DM), Hypertension (HTN), Systolic blood pressure (SBP), diastolic blood 
pressure (DBP), and heart rate (HR); we also collected data about the mean values and the standard deviation of the following outcomes at baseline, final, and change from baseline: EF, left ventricular end diastolic diameter (LVEDD), left ventricular end systolic diameter (LVESD), hospitalization for CHF, and infarction size.

\section{Statistical analysis}

All the statistical procedures were performed using Stata software version 13 (StataCorp LP, College Station, TX, USA). Mean change from baseline and its standard deviation (SD) for each outcome were extracted. In case the mean change was not reported, we calculated the mean changes and estimated SD using the correlation coefficient for the studies that reported baseline, after intervention, and change values. The weighted mean difference (WMD) and its corresponding SD were calculated using the DerSimonian and Laird method using a random effects model, which considers the betweenstudy variation. The heterogeneity between studies was assessed using the Cochran's Q test and I2. To find the possible sources of heterogeneity, we used metaregression and subgroup analysis. The variables sex, age ( $<65$ year vs. $\geq 65$ year), cell number, cell origin, time of transplantation, follow-up duration, rout of delivery, measurement tool, and primary intervention were specified for conducting subgroup analysis priory. The nonlinear potential effects for age, transplant time, follow-up duration, cell number, and baseline values were examined using fractional polynomial modeling. However, the number of studies in the subgroups was only sufficient in the subgroup analysis by cell number and time of transplantation. Moreover, we performed the analysis by excluding the studies with high risk of bias studies.

If at least 10 studies were available, we explored potential small-study effects, such as publication bias, using Egger's test and funnel plots. $p$ values $\leq 0.05$ were considered statistically significant. Influence analysis was performed to test the possible effect of individual studies on the final results.

\section{Results}

\section{Study identification and selection}

Figure 1 shows the PRISMA flow diagram of the study. In the initial search in databases, 1215 articles were identified; also 7 articles were found through other ways of search, of which 1150 references were excluded in the first screening. From 35 remaining articles, 13 studies with 956 patients (468 patients in the intervention arm and 488 in this systematic review and meta-analysis). Characteristics of the included clinical trials on the effect of stem cell therapy on acute myocardial infarction are presented in Table 1 . The articles were mostly published from 2010 to 2018 (2003-2021). The baseline LVEF of patients were in the range of 20.2 to 57.2 . The mesenchymal stem cells were injected through intracoronary route in ten studies, intramyocardial route in two studies, and intravenous in one study. The total cell numbers injected
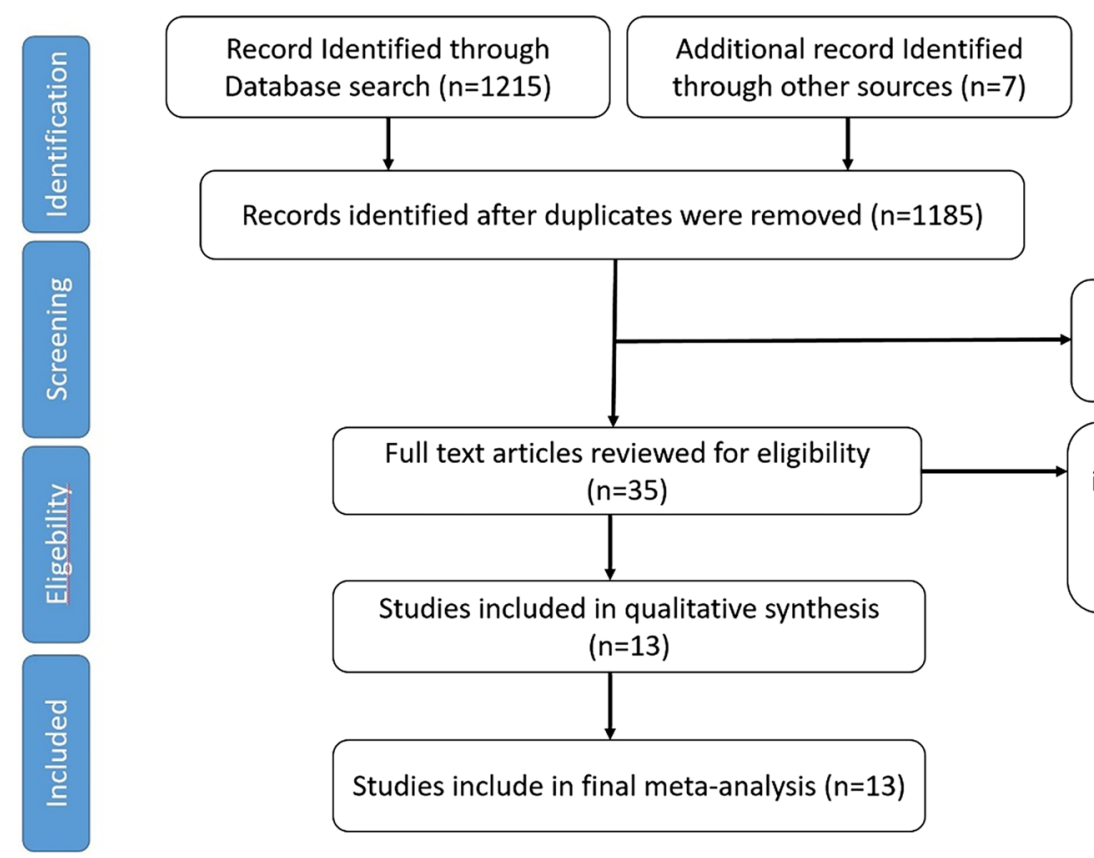

Records identified after duplicates were removed $(n=1185)$

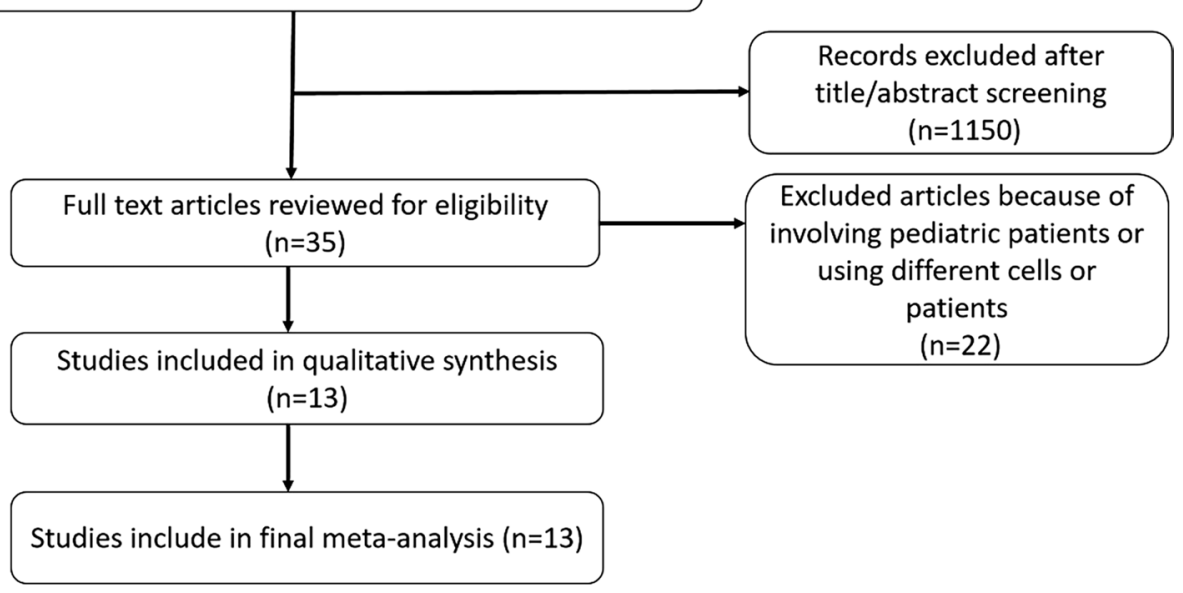

Fig. 1 PRISMA flow diagram of the study 
Table 1 Studies' characteristics

\begin{tabular}{|c|c|c|c|c|c|c|c|c|c|}
\hline Author & $\begin{array}{l}\text { Year of } \\
\text { publication }\end{array}$ & $\begin{array}{l}\text { Participant } \\
\text { comorbidity } \\
\text { number } \\
\text { DM(intervention, } \\
\text { control) } \\
\text { HTN(intervention, } \\
\text { control) }\end{array}$ & $\begin{array}{l}\text { Sample size } \\
\text { number } \\
\text { (intervention, } \\
\text { control) }\end{array}$ & $\begin{array}{l}\text { Age year } \\
\text { (intervention, } \\
\text { control) Mean } \\
\text { (SD) }\end{array}$ & $\begin{array}{l}\text { Gender } \\
\text { (intervention, } \\
\text { control) } \\
\text { Number of } \\
\text { females }\end{array}$ & $\begin{array}{l}\text { Cell } \\
\text { origin }\end{array}$ & $\begin{array}{l}\text { Route of } \\
\text { delivery }\end{array}$ & $\begin{array}{l}\text { Method of } \\
\text { measurement }\end{array}$ & $\begin{array}{l}\text { Follow-up } \\
\text { duration } \\
\text { (month) }\end{array}$ \\
\hline Hare & 2009 & $\begin{array}{l}6,1 \\
16,9\end{array}$ & 34,19 & $\begin{array}{l}59(12.3) \\
55.1(10.2)\end{array}$ & 6,4 & BMSC & IV & $\begin{array}{l}\text { Echocardiogra- } \\
\text { phy, MRI }\end{array}$ & 6 \\
\hline Gao & 2013 & $\begin{array}{l}6,5 \\
13,11\end{array}$ & 21,22 & $\begin{array}{l}55(1.6) \\
58.6(2.5)\end{array}$ & 0,3 & BMSC & IC & $\begin{array}{l}\text { Echocardiogra- } \\
\text { phy, SPECT }\end{array}$ & 24 \\
\hline Chen & 2004 & Not reported & 34,35 & $\begin{array}{l}58(7) \\
57(5)\end{array}$ & 2,1 & BMSC & IC & $\begin{array}{l}\text { Echocardiogra- } \\
\text { phy, PET }\end{array}$ & 3 \\
\hline $\begin{array}{l}\text { Chu- } \\
\text { likana }\end{array}$ & 2014 & Not reported & 10,10 & $\begin{array}{l}47.31(12.1) \\
47.79(6.48)\end{array}$ & 0,2 & BMSC & IC & $\begin{array}{l}\text { Echocardiogra- } \\
\text { phy, MRI, SPECT }\end{array}$ & 24 \\
\hline Penn & 2018 & $\begin{array}{l}1,2 \\
4,3\end{array}$ & 19,6 & $\begin{array}{l}53(9.9) \\
53(8)\end{array}$ & 1,1 & BMSC & IC & $\begin{array}{l}\text { Echocardiogra- } \\
\text { phy, angiog- } \\
\text { raphy }\end{array}$ & \\
\hline Lee & 2014 & $\begin{array}{l}5,8 \\
14,12\end{array}$ & 30,28 & $\begin{array}{l}53.9(10.5) \\
54.2(7.7)\end{array}$ & 3,3 & BMSC & IC & $\begin{array}{l}\text { Echocardiogra- } \\
\text { phy, SPECT }\end{array}$ & $182.6,179.5$ \\
\hline Rodrigo & 2013 & $\begin{array}{l}1,5 \\
4,18\end{array}$ & 9,45 & $\begin{array}{l}56(8) \\
61(11)\end{array}$ & 2,10 & BMSC & IM & $\begin{array}{l}\text { Echocardiogra- } \\
\text { phy, SPECT }\end{array}$ & 54.3 \\
\hline Gao & 2015 & $\begin{array}{l}17,14 \\
33,26\end{array}$ & 58,58 & $\begin{array}{l}57.3(103) \\
56.7(1.7)\end{array}$ & 3,7 & $\begin{array}{l}\text { Umbli- } \\
\text { cal }\end{array}$ & IC & $\begin{array}{l}\text { Echocardiogra- } \\
\text { phy, SPECT }\end{array}$ & 18 \\
\hline Wang & 2014 & Not reported & 28,30 & $\begin{array}{l}56.1(9.8) \\
58(10.2)\end{array}$ & 16,9 & BMSC & IC & $\begin{array}{l}\text { Echocardiogra- } \\
\text { phy, angiog- } \\
\text { raphy }\end{array}$ & 6 \\
\hline $\begin{array}{l}\text { Kharla- } \\
\text { mov }\end{array}$ & 2007 & $\begin{array}{l}45,48,55 \\
131,127,132\end{array}$ & $131,127,132$ & $\begin{array}{l}58.32(9.12) \\
59.44(10.26) \\
57.25(7.68)\end{array}$ & $8,8,15$ & $\begin{array}{l}\text { autolo- } \\
\text { gous, } \\
\text { adipose }\end{array}$ & $\mathrm{IM}$ & $\begin{array}{l}\text { Echocardiogra- } \\
\text { phy, angiogra- } \\
\text { phy, SPECT }\end{array}$ & 12 \\
\hline $\begin{array}{l}\text { Haut- } \\
\text { graff }\end{array}$ & 2012 & $\begin{array}{l}\text { Not reported } \\
6,2\end{array}$ & 9,4 & $\begin{array}{l}61(2.1) \\
55(7.5)\end{array}$ & 2,0 & Adipose & IC & SPECT & 36 \\
\hline Kim & 2018 & $\begin{array}{l}3,2 \\
5,5\end{array}$ & $\begin{array}{l}14,12 \\
14,12\end{array}$ & $\begin{array}{l}56.45 \\
56.45\end{array}$ & 0,0 & BMSC & IC & $\begin{array}{l}\text { SPECT } \\
\text { Echocardiog- } \\
\text { raphy }\end{array}$ & 6 \\
\hline Zhang & 2021 & $\begin{array}{l}8,5 \\
13,11\end{array}$ & 21,22 & 58.94 & 1,3 & BMSC & IC & $\begin{array}{l}\text { Echocardiog- } \\
\text { raphy }\end{array}$ & 12 \\
\hline
\end{tabular}

were between 2.3 and $85 \times 10^{6}$. The mean duration of patients' follow-up after transplantation was between 6 and 182.6 months. The sample sizes were in the range of 13-390 patients. All studies had performed PCI as the primary intervention, except one that had performed thrombolytic therapy. Twelve studies used echocardiography as a measurement tool, eight studies used SPECT, three used angiography, and just two studies used MRI for measuring ejection fraction (Table 1) [13, 15-26].

\section{Quality assessment of studies}

Quality assessment of studies is presented in Table 2. Among the thirteen studies, one was non-randomized [18] and five studies did not report the method of randomization [17, 19, 20, 22, 24]. Five articles had low risk of allocation concealment [13, 15, 16, 21, 23]. Only seven studies were blinded to the participants or researcher $[13,15,20,21,23,25,26]$; two studies were not blind $[16,19]$, and four were unclear $[17,18,22$, $24]$. Outcomes blinding for assessors was good in nine articles [13, 15-17, 19-21, 23, 25]. Two studies had incomplete outcome data $[15,19,23]$, but the others were at low risk. No article had selective reporting. As a whole, three studies were judged as having good quality $[13,21,25]$, five poor $[18,19,22,24]$, and three fair [20, $23,26]$ qualities.

\section{LVEF}

Although pooled analysis of 13 studies (956 patients) revealed no significant change in LVEF (WMD $=3.868 \%$, 95\% CI: -1.699 to $9.435, p=0.173, I^{2}=99.9 \%$ ), however, excluding studies with poor quality and high risk of bias showed a significant increase (WMD $=3.78 \%, 95 \% \mathrm{CI}$ : 2.14 to $5.42, p<0.001, I^{2}=90.2 \%$; Fig. 2 ). 
Table 2 Quality assessment analysis

\begin{tabular}{|c|c|c|c|c|c|c|c|}
\hline $\mathrm{RCT}$ & $\begin{array}{l}\text { Random } \\
\text { sequence } \\
\text { generation }\end{array}$ & $\begin{array}{l}\text { Allocation } \\
\text { concealment }\end{array}$ & $\begin{array}{l}\text { Blinding of } \\
\text { participants and } \\
\text { personnel }\end{array}$ & $\begin{array}{l}\text { Blinding of } \\
\text { outcome } \\
\text { assessors }\end{array}$ & $\begin{array}{l}\text { Incomplete } \\
\text { outcome data }\end{array}$ & $\begin{array}{l}\text { Selective } \\
\text { reporting }\end{array}$ & \\
\hline Chen et al. [22] & U & $U$ & $U$ & $U$ & $L$ & L & Poor \\
\hline Chullikana et al. [21] & L & L & L & L & $L$ & L & Good \\
\hline Gao et al. [15] & L & L & L & L & $\mathrm{H}$ & L & Fair \\
\hline Gao et al. [16] & L & L & $\mathrm{H}$ & L & $L$ & L & Fair \\
\hline Hare et al. [23] & L & $L$ & L & L & $\mathrm{H}$ & L & Fair \\
\hline Lee et al. [19] & $U$ & $U$ & $\mathrm{H}$ & L & $\mathrm{H}$ & L & Poor \\
\hline Wang et al. [17] & U & $U$ & $U$ & $L$ & $L$ & L & Poor \\
\hline Kharlamov et al. [24] & $U$ & $U$ & $U$ & $U$ & $L$ & L & Poor \\
\hline Houtgraaf et al. [13] & L & L & $L$ & L & $L$ & L & Good \\
\hline Rodrigo et al. [18] & $\mathrm{H}$ & U & $U$ & $U$ & $L$ & L & Poor \\
\hline Penn et al. [20] & $U$ & U & L & $L$ & $L$ & L & Fair \\
\hline Kim et al. [25] & L & U & L & L & $L$ & L & Good \\
\hline Zhang et al. [26] & L & U & L & U & $\mathrm{L}$ & L & Fair \\
\hline
\end{tabular}

$H$ : high risk, U: unclear risk, L: low risk (Cochrane Handbook For Systematic Reviews Of Intervention)

\section{Other echocardiographic indices}

The observed change in LVEDV that was measured by seven studies was not significant (WMD - $5.076 \mathrm{ml}, 95 \%$ $\mathrm{Cl},-11.909$ to $1.757, \quad p \quad$ value $=0.145, \quad I^{2}=96.2 \%$; the reduction in LVEDV remained nonsignificant after excluding the four studies with high risk of bias $(\mathrm{WMD}=-5.985 \mathrm{ml}, 95 \% \mathrm{CI},-15.907$ to $3.938, p$ value $=0.237, \quad I^{2}=95.1 \%$ ). The change in LVESV, as a pooled analysis of six studies, was not significant $(\mathrm{WMD}=-2.892 \mathrm{ml}, 95 \% \mathrm{Cl},-6.779$ to $0.995, p$ value $\left.=0.145, I^{2}=38.4 \%\right)$ and after excluding the three studies with high risk of bias, the reduction was greater and still marginally nonsignificant (WMD $=-5.963 \mathrm{ml}$, $95 \% \mathrm{CI},-12.18$ to 0.26 , $p$ value $=0.17, I^{2}=43.8 \%$ ); (Additional file 1).

\section{Infarct size}

No significant change was observed in the infarct size as a pooled analysis of three studies on 91 patients $(\mathrm{WMD}=-5.12,95 \% \mathrm{Cl}-20.73$ to $10.50, p$ value $=0.52$, $\left.I^{2}=86.7\right)$. After excluding the results from a study which quality control showed that it has poor quality with high chance of bias, the analysis revealed a significant decrease in the infarct size (WMD $=-8.91,95 \% \mathrm{Cl}-22.08$ to 4.26 , $p$ value $=0.002, I^{2}=100$; Additional file 2).

\section{Hospitalization for heart failure}

Analysis of seven studies with 315 participants indicated that 21 out of 191 patients (10.99\%) in the intervention group and 21 out of 167 patients (12.57\%) in the control group were hospitalized due to heart failure, which showed no significant therapeutic effect $(R R=0.882$, $95 \% \mathrm{Cl} 0.563$ to $1.381, p$ value $=0.584$ ). Only one study had a high risk of bias; excluding this study did not have a serious effect on the result $(\mathrm{RR}=0.917,95 \% \mathrm{Cl} 0.580$ to $1.450, p$ value $=0.712$ ).

\section{Subgroup analyses}

Transplantation of MSC within the first week after AMI significantly increased LVEF by $5.740 \%$ (95\% CI 4.297 to 7.183; $p$ value $<0.001 ; I^{2}=79.2 \%$ ), but not after 1 week by $(\mathrm{WMD}=1.16 \%, 95 \% \mathrm{CI}-5.417$ to $7.733 ; p$ value $=0.730$; $I^{2}=99.2 \% \%$, and after exclusion of high risk of bias studies $\mathrm{WMD}=1.85 \% ; 95 \% \mathrm{CI}-0.61$ to $4.31 ; I^{2}=80.7 \%$; $p=0.14$; Fig. 3).

To perform a subgroup analysis for route of delivery, after excluding poor quality trials biased studies, we found no significant difference between the group effects on EF. Also, it should be noted that in two routes, only one study was performed: Intravenous (WMD 3.90, $95 \% \mathrm{Cl} 1.99$ to $5.81, p<0.001$ ), Intramyocardial (Subendocardial) (WMD $4.00,95 \% \mathrm{Cl} 2.74$ to $5.26, p<0.001$ ), and Intracoronary (WMD 3.57, $95 \% \mathrm{Cl} 1.91$ to $5.22, p<0.001$; Fig. 4).

According to subgroup analysis done for follow-up duration, the efficacy of this new treatment has become more obvious after following the patients for more than 12 months both before and after excluding the biased studies $(\mathrm{WMD}=4.21,95 \% \mathrm{Cl} 2.95$ to $5.46, p$ value $<0.001$; Additional file 3). Between-group analysis was done, and the difference was significant ( $p$ between group $<0.001$ ).

Performance of a subgroup analysis for cell source revealed that umbilical cord-derived stem cells had a 
A
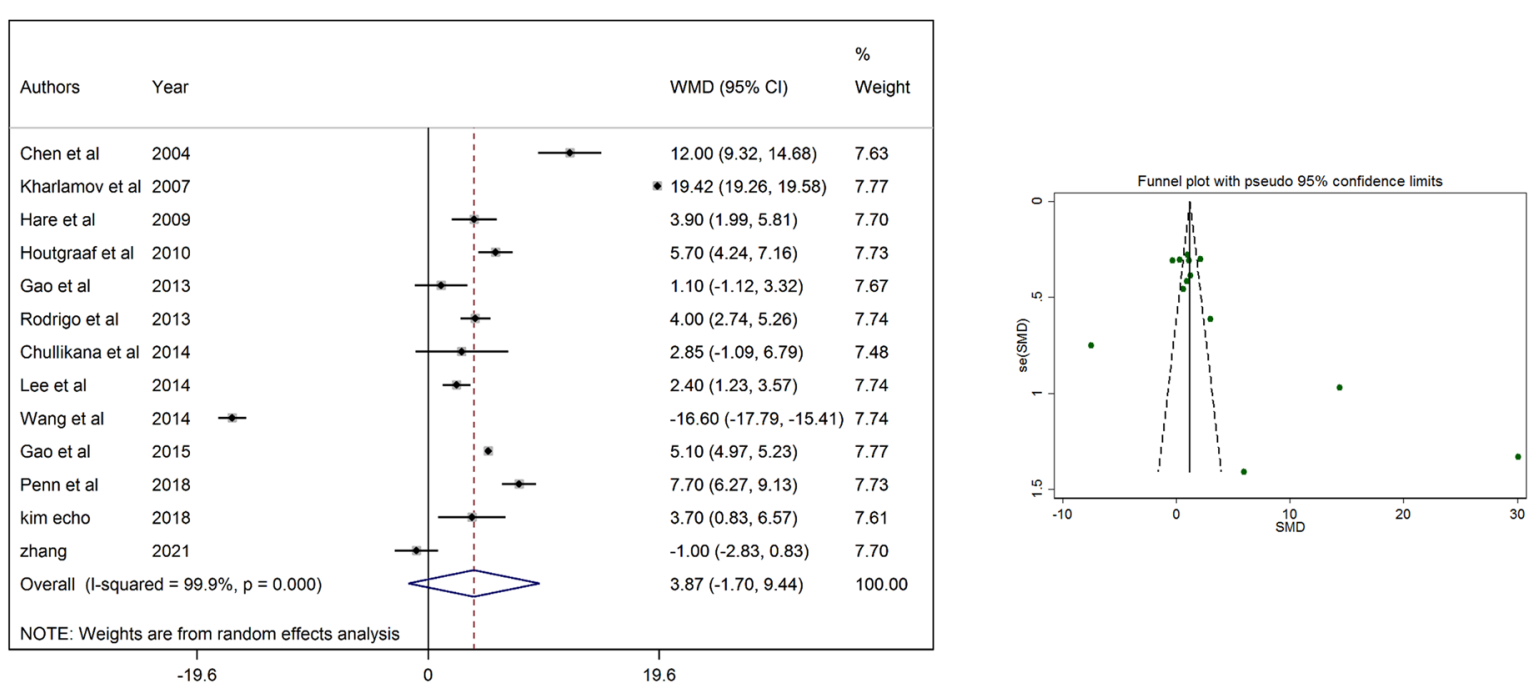

B

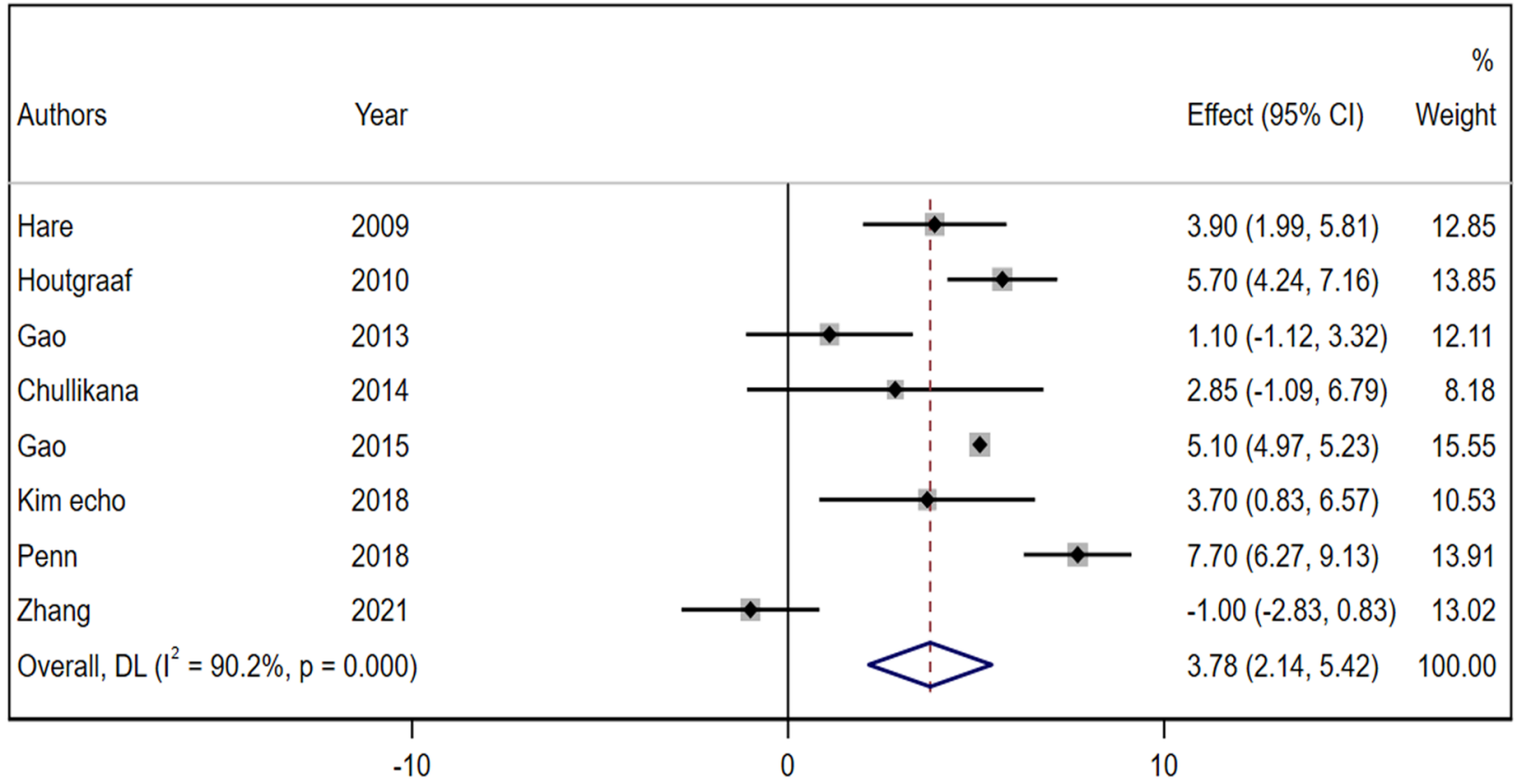

Fig. 2 A Forest and funnel plot for ejection fraction before excluding the biased studies $\mathbf{B}$ forest plot for ejection fraction after excluding biased studies WMD weighted mean difference $\mathrm{Cl}$ confidence interval

more positive effect on $\mathrm{EF}(\mathrm{WMD}=5.1,95 \% \mathrm{Cl} 4.239$ to $7.161, p$ value $<0.001)$ in comparison with bone marrow derived cells $(\mathrm{WMD}=1.98,95 \% \mathrm{Cl} 1.813$ to 5.714 , $p$ value $\left.=0.498, I^{2}=87.4\right)$ and adipose derived cells $(\mathrm{WMD}=5.1,95 \% \mathrm{Cl} 4.971$ to $5.229, p$ value $=0.067$; Additional file 4).

Comparison between MSC injections higher or lower than $10^{7}$ exhibited no statistically significant LVEF improvement $(4.81(95 \% \mathrm{Cl}-5.37$ to $14.99, p=0.354)$ vs.
$2.36(95 \% \mathrm{Cl}-0.62$ to $5.34, p=0.121))$. In spite of this finding, after excluding the biased studies, analysis showed that cell injections lower than $10^{7}$ could significantly improve LVEF more $(4.55$ [95\% Cl 3.92 to $5.17, p<0.001$ ] vs. 5.05$] 95 \% \mathrm{Cl} 4.92$ to $5.18, p=0.121$ ]; Additional file 5).

\section{Meta-regression analysis}

Meta-regression analyses for age (Additional file 6), follow-up duration, transplant time, cell number, and the 


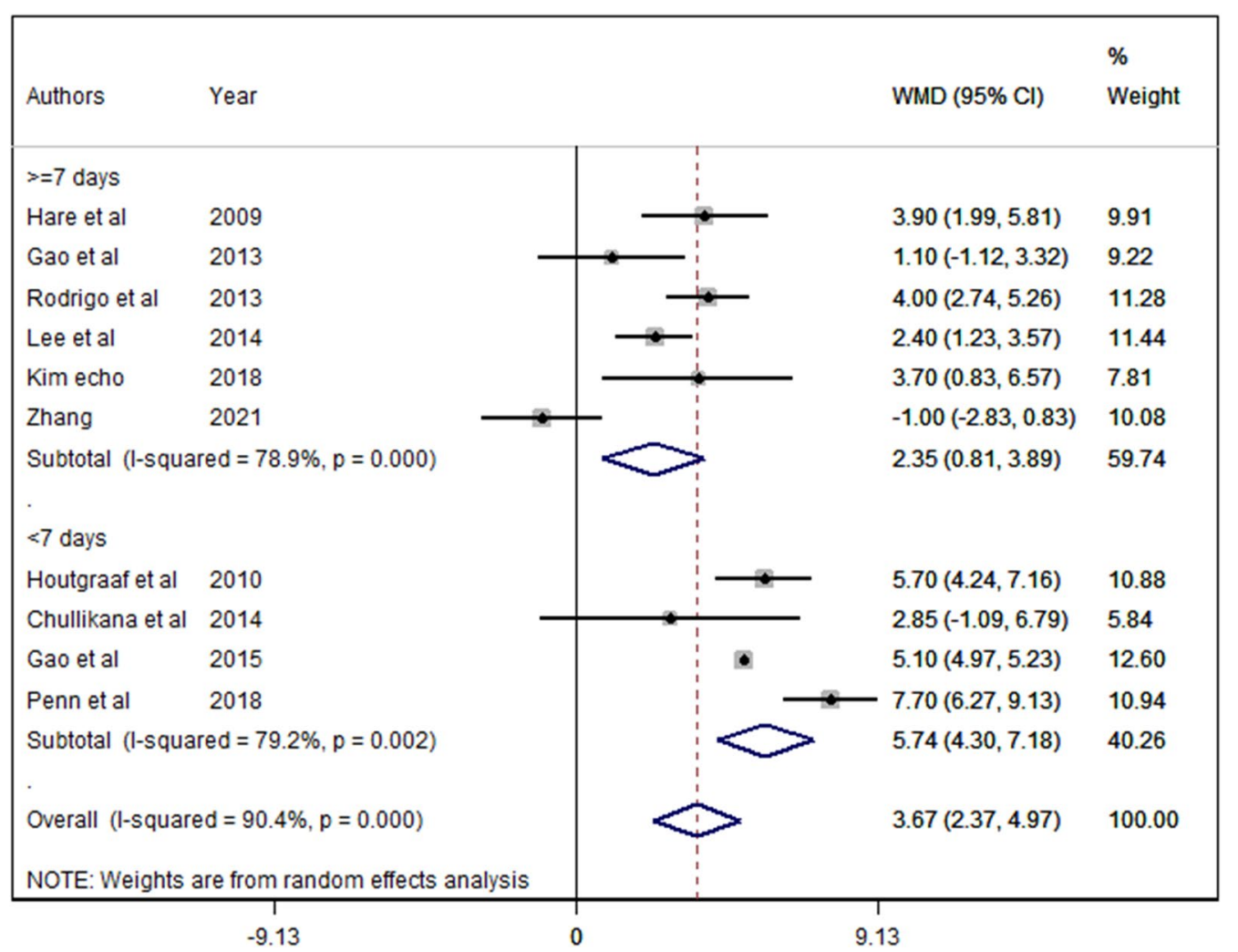

Fig. 3 Subgroup analysis for the time interval between AMI and transplantation after excluding the biased studies WMD weighted mean difference Cl confidence interval

baseline values did not show a significant trend for LVEF either in presence or after excluding high risk of bias studies. Similarly, when we evaluated dose-responses, there was no evidence for nonlinear dose response relations between the abovementioned variables and LVEF.

\section{Publication bias and sensitivity analysis}

Although a slight asymmetry was seen in the funnel plots (Additional file 7), there was no evidence for publication bias based on Egger's test $(p=0.131)$.

\section{Discussion}

In the present study, by including 13 RCTs and 956 patients, we found that MSC therapy improved LVEF after AMI by $3.67 \%$; if this therapy was performed within the first week, its effect might increase to $5.74 \%$. Also, when transplantation dose was less than $10^{7}$ cells, it might improve LVEF as well. To the best of our knowledge, this meta-analysis is the largest available metaanalysis in the field. Most of available previous studies have included both acute and chronic ischemic diseases [27] or have enrolled animal studies [28] to increase the population number; if they did not do it, the analysis was done with a sample size less than 450 studies and at most of eight trials [29, 30]. Our study is almost twice as large as previous meta-analyses.

Since the introduction of regenerative medicine in cardiology, many clinical trials have been conducted to evaluate various types of cells. Among them, BM-MNCs have been studied widely and most of our knowledge about stem cell therapy in AMI is derived from those studies. We asked questions such as "When should these cells be transplanted?", "From which route?" and "in which patients?" in BM-MNCs trials, but not in MSCs. Consequently, performance of meta-analysis for MSCs to answer these questions seemed essential.

Meta-analyses of BM-MNCs trials including those with a patients' level data have indicated that transplantation of BM-MNC after AMI may improve LVEF by $2.72 \%$ [9]. In our study, we noticed an LVEF improvement of $3.67 \%$ by transplantation of MSC. This finding is similar to the results of TAC-HFT trial. In that study, it was shown that MSCs were about twice as much effective as the BMMNCs [10]. Furthermore, in the POSIEDON trial, it was shown that allogenic MSC was as safe and effective as autologous ones [31]. This gives MSCs the potential to be used as off the shelf. These characteristics make MSCs a 


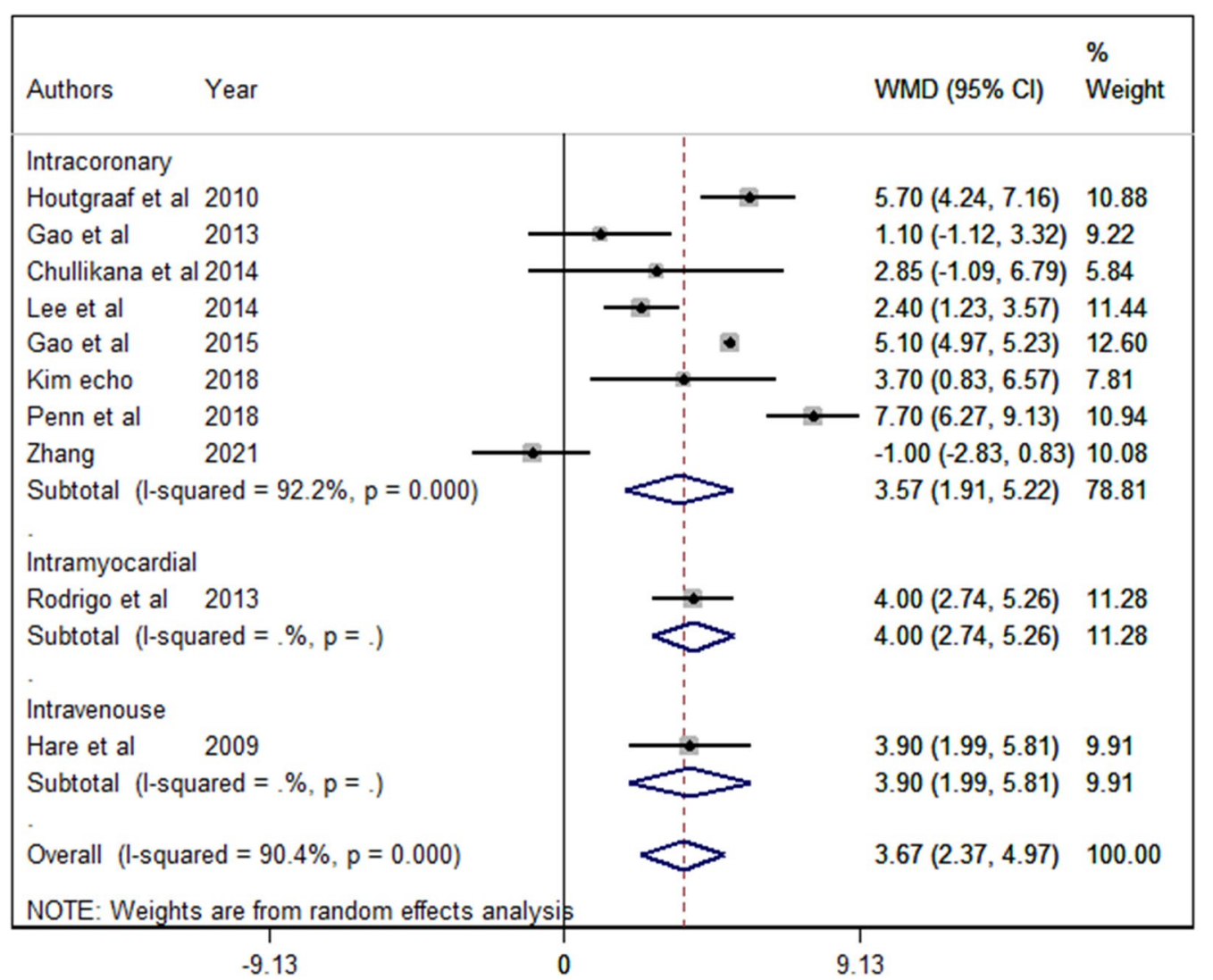

Fig. 4 Subgroup analysis for the route of delivery after excluding the biased studies

more attractive and effective source of cell in regenerative cardiology as compared to BM-MNCs.

The role of timing on the effect of stem cell therapy after AMI has been widely investigated in BM-MNCs trials, but not on MSCs. In the Regenerate AMI (transplantation within 24 h) [32], TIME (transplantation within 1 week) [33], and Late TIME (transplantation after 2-3 weeks) [34] trials, the effect of timing on the efficacy of BM-MNCs on LVEF was assessed. Results of the mentioned trials and pool patient data meta-analyses [35, 36] revealed that the best transplantation time after AMI to improve the myocardial function would be 3-7 days after AMI. If it is done sooner, it may cause loss of transplanted stem cells due to the high inflammatory status within the myocardium and later may reduce the effect as myocyte loss and fibrosis will be stablished. No trial has evaluated this issue for MSCs, and our meta-analysis has paved the way in the field.

The effect of the number of intracoronary MSCs transplanted on the myocardial function recovery has been investigated in animal and preclinical studies. In the pig model, Fiarresga et al. have shown that a higher number of intracoronary transplanted MSCs would increase the chance of microvascular obstruction and myocardial injury [37]. A similar finding in sheep was also noticed [38]. Our finding regarding the effect of cell number is in agreement with those of animal studies.

The exact mechanisms accounting for the beneficial effects of using stem cells in AMI in preclinical and clinical studies are not clear. The data supporting the theory on differentiation of the transplanted cells as a mechanism of improvement in the recipient heart are very poor; even if all of the remaining cells are transformed into the cardiomyocytes, it would not be sufficient to account for the useful effects reported [39]. Differentiation of the transplanted cells into new vessels has been observed in different cells, such as MSCs [40], and it has been suggested that vasculogenesis may result in rescuing the cardiomyocytes in the hypoxic area. It is challenging to imagine (consider) how the 
vasculogenesis mechanism could be a main mechanism in patients who had already successful coronary revascularization after an AMI; however, it is obvious that this phenomenon can be responsible for some of the advantageous effects of cell therapy. Recently, the paradigm has shifted from these mechanisms to the paracrine effect theory, which suggests that most of the beneficial effects after cell therapy are obtained through signals such as cytokines that are released in a paracrine signaling by the injected cells and alter the nearby cells and the recipient heart [41].

Since the efficacy of MSC therapy after AMI seems to be limited, many investigators have tried to enhance the quality of these cells before transplantations. Lin and colleagues suggested that addition of IGF-1 would enhance viability, migration, and anti-apoptosis of MSC in myocardial infarction [42]. Wu and coworkers assessed the role of sFRP2 in this situation [43], and Huang et al. assessed the role of Secreted frizzled-related proteins (Sfrps) [44].

This study had some limitations. The most important one is that three trials had reported results that were significantly incompatible with the findings of other studies. Although the final results of including and excluding them were nearly similar, due to development of a large LVEF change interval, the results would become significant only by excluding them $[(\mathrm{WMD}=3.87 \%, 95 \%$ CI: -1.699 to $9.435, p=0.173$ ) vs. (WMD $=3.673 \%, 95 \%$ CI: 2.374 to $4.973, p<0.001)]$. The other issue that should be addressed is that the baseline LVEF enrolled in the trials was not similar; this might have affected the final results. Another important hint is that most of studies used echocardiography as their main method of LVEF assessment. However, cardiac MRI with the potential to show myocardial fibrosis and scar size and mass may be a more accurate way of assessment.

\section{Conclusion}

It can be concluded that transplantation of MSCs after AMI significantly increases LVEF. Performing the operation within the first week after AMI might augment this efficacy. Performance of a large clinical trial in future to see if MSC transplantation can help prevent hospitalization form heart failure after AMI seems to be necessary. The PREVENT-TAHA trial (https://clinicaltrial.gov, NCT05043610.) will help finding the answer.

\footnotetext{
Abbreviations

AMl: Acute myocardial infarction; BM-MNC: Bone marrow derived mononuclear cell; CHF: Congestive heart failure; LVEDD: Left ventricular end diastolic diameter; LVEF: Left ventricular ejection fraction; LVESD: Left ventricular end systolic diameter; MSC: Mesenchymal stem cell; RCT: Randomized controlled trial.
}

\section{Supplementary Information}

The online version contains supplementary material available at https://doi. org/10.1186/s13287-021-02667-1.

Additional file 1. Forest plot for the left ventricular end diastolic diameter (Top) left ventricular end systolic diameter (Bottom) WMD weighted mean difference $\mathrm{Cl}$ confidence interval.

Additional file 2. Forest plot for infarction size before (top) and after (Botteom) excluding the biased studies.

Additional file 3. Subgroup analysis for the follow-up duration.

Additional file 4. Subgroup analysis for stem cell resource.

Additional file 5. Subgroup analysis for the number of cells transplanted before and after excluding the biased studies.

Additional file 6 . Dose response analysis for age before (top) and after (Bottom) excluding the biased studies.

Additional file 7. Publication bias analysis.

\section{Acknowledgements}

The authors would like to thank Center for Development of Clinical Research of Nemazee Hospital and Dr. Nasrin Shokrpour for editorial assistance.

\section{Authors' contributions}

SK and FB contributed to the provision of study materials or patient data, data analysis, interpretation of trials, and drafting the manuscript. When there was divergence between the data extractors, AA consolidated the data, as described in the methodology of the article. AA and AK contributed to the concept and design of the study and statistical analysis, administrative support, and final approval of manuscript. They also contributed to the concept and design of the study and statistical analysis, administrative support, and final approval of the manuscript and assisted in manuscript writing and funding supply. AM help performing new analyses and drafting the revision of manuscript. All authors read and approved the final manuscript.

\section{Funding}

This study is extracted from a thesis supported by a grant with the code of 17045 from vice-chancellery of research in Shiraz University of Medical Sciences.

Availability of data and materials

The original data are available from the corresponding author on request.

\section{Declarations}

Ethics approval and consent to participate

This study is approved by local Ethics committee by approval number IR.SUMS.MED.REC.1399.557.

Consent for publication

Not applicable.

\section{Competing interests}

The authors declare that they have no competing interests.

\section{Author details}

${ }^{1}$ Department of Cardiovascular Medicine, TAHA Clinical Trial Group, School of Medicine, Shiraz University of Medical Sciences, Zand Street, Shiraz, Iran. ${ }^{2}$ Students' Research Committee, Shiraz University of Medical Sciences, Shiraz, Iran. ${ }^{3}$ Hematology Research Center, Shiraz University of Medical Sciences, Shiraz, Iran. ${ }^{4}$ Department of Pathology, Shiraz University of Medical Sciences, Shiraz, Iran. ${ }^{5}$ Nutrition Research Center, Shiraz University of Medical Sciences, PO Box 71645-111, Shiraz, Iran.

Received: 9 September 2021 Accepted: 18 November 2021

Published online: 07 December 2021 


\section{References}

1. Organization WH. The global burden of disease: 2004 update. Geneva: World Health Organization; 2008.

2. Velagaleti RS, Pencina MJ, Murabito JM, Wang TJ, Parikh NI, D'Agostino RB, et al. Long-term trends in the incidence of heart failure after myocardial infarction. Circulation. 2008;118(20):2057-62

3. Yancy CW, Jessup M, Bozkurt B, Butler J, Casey DE Jr, Colvin MM, et al. 2016 ACC/AHA/HFSA Focused Update on New Pharmacological Therapy for Heart Failure: An Update of the 2013 ACCF/AHA Guideline for the Management of Heart Failure: A Report of the American College of Cardiology/American Heart Association Task Force on Clinical Practice Guidelines and the Heart Failure Society of America. Circulation. 2016:134(13):e282-93.

4. Lewis EF, Moye LA, Rouleau JL, Sacks FM, Arnold JM, Warnica JW, et al. Predictors of late development of heart failure in stable survivors of myocardial infarction: the CARE study. J Am Coll Cardiol. 2003;42(8):1446-53.

5. Juillière Y, Cambou JP, Bataille V, Mulak G, Galinier M, Gibelin P, et al. Heart failure in acute myocardial infarction: a comparison between patients with or without heart failure criteria from the FAST-MI registry. Revista Española de Cardiología (English Edition). 2012;65(4):326-33.

6. Braunwald E. Cell-Based Therapy in Cardiac Regeneration: An Overview. Circ Res. 2018;123(2):132-7.

7. Menasché $P$, Hagège AA, Scorsin $M$, Pouzet $B$, Desnos $M$, Duboc $D$, et al. Myoblast transplantation for heart failure. Lancet (London, England). 2001;357(9252):279-80.

8. Assmus B, Schächinger $V$, Teupe C, Britten M, Lehmann R, Döbert N, et al. Transplantation of progenitor cells and regeneration enhancement in acute myocardial infarction (TOPCARE-AMI). Circulation. 2002;106(24):3009-17.

9. Fisher SA, Zhang H, Doree C, Mathur A, Martin-Rendon E. Stem cell treatment for acute myocardial infarction. Cochrane Database Syst Rev. 2015(9):Cd006536.

10. Heldman AW, DiFede DL, Fishman JE, Zambrano JP, Trachtenberg BH, Karantalis V, et al. Transendocardial mesenchymal stem cells and mononuclear bone marrow cells for ischemic cardiomyopathy: the TAC-HFT randomized trial. JAMA. 2014:311(1):62-73.

11. Williams A, Hare J. Mesenchymal stem cells: biology, pathophysiology, translational findings, and therapeutic implications for cardiac disease. Circ Res. 2011;109:923-40

12. Dominici M, Le Blanc K, Mueller I, Slaper-Cortenbach I, Marini FC, Krause DS, et al. Minimal criteria for defining multipotent mesenchymal stroma cells. The International Society for Cellular Therapy position statement. Cytotherapy. 2006;8(4):315-7.

13. Houtgraaf $J H$, den Dekker WK, van Dalen BM, Springeling $T$, de Jong $R$, van Geuns RJ, et al. First experience in humans using adipose tissuederived regenerative cells in the treatment of patients with ST-segment elevation myocardial infarction. J Am Coll Cardiol. 2012;59(5):539-40.

14. Karantalis V, Schulman I, Balkan W, Hare J. Allogeneic cell therapy a new paradigm in therapeutics. Circ Res. 2015;116:12-5.

15. Gao LR, Pei XT, Ding QA, Chen Y, Zhang NK, Chen HY, et al. A critical challenge: dosage-related efficacy and acute complication intracoronary injection of autologous bone marrow mesenchymal stem cells in acute myocardial infarction. Int J Cardiol. 2013;168(4):3191-9.

16. Gao LR, Chen Y, Zhang NK, Yang XL, Liu HL, Wang ZG, et al. Intracoronary infusion of Wharton's jelly-derived mesenchymal stem cells in acute myocardial infarction: double-blind, randomized controlled trial. BMC Med. 2015;13(1):1-15

17. Wang X, Xi W-C, Wang F. The beneficial effects of intracoronary autologous bone marrow stem cell transfer as an adjunct to percutaneous coronary intervention in patients with acute myocardial infarction. Biotechnol Lett 2014;36(11):2163-8.

18. Rodrigo SF, van Ramshorst J, Hoogslag GE, Boden H, Velders MA, Cannegieter SC, et al. Intramyocardial injection of autologous bone marrowderived ex vivo expanded mesenchymal stem cells in acute myocardial infarction patients is feasible and safe up to 5 years of follow-up. $J$ Cardiovasc Transl Res. 2013;6(5):816-25.

19. Lee J-W, Lee S-H, Youn Y-J, Ahn M-S, Kim J-Y, Yoo B-S, et al. A randomized open-label, multicenter trial for the safety and efficacy of adult mesenchymal stem cells after acute myocardial infarction. J Korean Med Sci. 2014;29(1):23-31
20. Penn MS, Ellis S, Gandhi S, Greenbaum A, Hodes Z, Mendelsohn FO, et al. Adventitial delivery of an allogeneic bone marrow-derived adherent stem cell in acute myocardial infarction: phase I clinical study. Circ Res. 2012;110(2):304-11.

21. Chullikana A, Majumdar AS, Gottipamula S, Krishnamurthy S, Kumar AS, Prakash $V$, et al. Randomized, double-blind, phase I/II study of intravenous allogeneic mesenchymal stromal cells in acute myocardial infarction. Cytotherapy. 2015;17(3):250-61.

22. Chen S-I, Fang W-W, Ye F, Liu Y-H, Qian J, Shan S-j, et al. Effect on left ventricular function of intracoronary transplantation of autologous bone marrow mesenchymal stem cell in patients with acute myocardial infarction. Am J Cardiol 2004;94(1):92-5.

23. Hare JM, Traverse JH, Henry TD, Dib N, Strumpf RK, Schulman SP, et al. A randomized, double-blind, placebo-controlled, dose-escalation study of intravenous adult human mesenchymal stem cells (prochymal) after acute myocardial infarction. J Am Coll Cardiol. 2009:54(24):2277-86.

24. Kharlamov A, Smolenskaya O, Gabinsky YL, Bos E. Comparative analysis of intramyocardial autotransplantation of postnatal stem cells from peripheral blood and adipose tissue in patients with acute phase of myocardial infarction, ST segment elevation, after effective thrombolytic reperfusion and coronary artery stenting. Кардиоваскулярная терапия и профилактика. 2007;6(8):52.

25. Kim SH, Cho JH, Lee YH, Lee JH, Kim SS, Kim MY, et al. Improvement in left ventricular function with intracoronary mesenchymal stem cell therapy in a patient with anterior wall ST-segment elevation myocardial infarction. Cardiovasc Drugs Ther. 2018;32(4):329-38.

26. Zhang R, Yu J, Zhang N, Li W, Wang J, Cai G, et al. Bone marrow mesenchymal stem cells transfer in patients with ST-segment elevation myocardial infarction: single-blind, multicenter, randomized controlled trial. Stem Cell Res Ther. 2021;12(1):33.

27. Jeong $\mathrm{H}$, Yim HW, Park HJ, Cho Y, Hong H, Kim NJ, et al. Mesenchymal stem cell therapy for ischemic heart disease: systematic review and metaanalysis. Int J Stem Cells. 2018;11(1):1-12.

28. Kanelidis AJ, Premer C, Lopez J, Balkan W, Hare JM. Route of delivery modulates the efficacy of mesenchymal stem cell therapy for myocardial infarction: a meta-analysis of preclinical studies and clinical trials. Circ Res. 2017;120(7):1139-50.

29. Wang Z, Wang L, Su X, Pu J, Jiang M, He B. Rational transplant timing and dose of mesenchymal stromal cells in patients with acute myocardial infarction: a meta-analysis of randomized controlled trials. Stem Cell Res Ther. 2017;8(1):1-10.

30. Wu H, Cao H. Efficacy and safety of mesenchymal stromal cells on left ventricular function after acute myocardial infarction: a meta-analysis of randomized controlled trials. Int J Clin Exp Med. 2017;10(4):5871-82.

31. Hare JM, Fishman JE, Gerstenblith G, DiFede Velazquez DL, Zambrano JP, Suncion VY, et al. Comparison of allogeneic vs autologous bone marrowderived mesenchymal stem cells delivered by transendocardial injection in patients with ischemic cardiomyopathy: the POSEIDON randomized trial. JAMA. 2012:308(22):2369-79.

32. Choudry F, Hamshere S, Saunders N, Veerapen J, Bavnbek K, Knight C, et al. A randomized double-blind control study of early intra-coronary autologous bone marrow cell infusion in acute myocardial infarction: the REGENERATE-AMI clinical trialt. Eur Heart J. 2016:37(3):256-63.

33. Traverse JH, Henry TD, Pepine CJ, Willerson JT, Zhao DX, Ellis SG, et al. Effect of the use and timing of bone marrow mononuclear cell delivery on left ventricular function after acute myocardial infarction: the TIME randomized trial. JAMA. 2012;308(22):2380-9.

34. Traverse JH, Henry TD, Ellis SG, Pepine CJ, Willerson JT, Zhao DX, et al. Effect of intracoronary delivery of autologous bone marrow mononuclear cells 2 to 3 weeks following acute myocardial infarction on left ventricular function: the LateTIME randomized trial. JAMA. 2011;306(19):2110-9.

35. Zhang S, Sun A, Xu D, Yao K, Huang Z, Jin H, et al. Impact of timing on efficacy and safetyof intracoronary autologous bone marrow stem cells transplantation in acute myocardial infarction: a pooled subgroup analysis of randomized controlled trials. Clin Cardiol. 2009;32(8):458-66.

36. Delewi R, Hirsch A, Tijssen JG, Schächinger V, Wojakowski W, Roncalli J, et al. Impact of intracoronary bone marrow cell therapy on left ventricular function in the setting of ST-segment elevation myocardial infarction: a collaborative meta-analysis. Eur Heart J. 2014;35(15):989-98.

37. Fiarresga A, Mata MF, Cavaco-Gonçalves S, Selas M, Simões IN, Oliveira E, et al. Intracoronary delivery of human mesenchymal/stromal stem cells: 
insights from coronary microcirculation invasive assessment in a swine model. PLoS ONE. 2015;10(10):e0139870.

38. Grieve SM, Bhindi R, Seow J, Doyle A, Turner AJ, Tomka J, et al. Microvascular obstruction by intracoronary delivery of mesenchymal stem cells and quantification of resulting myocardial infarction by cardiac magnetic resonance. Circ Heart Fail. 2010;3(3):e5-6.

39. Hong K, Guo Y, Li Q-H, Cao P, Al-Maqtari T, Vajravelu B, et al. c-kit+ cardiac stem cells alleviate post-myocardial infarction left ventricular dysfunction despite poor engraftment and negligible retention in the recipient heart. PLoS ONE. 2014;9:e96725.

40. Cai L, Johnstone B, Cook T, Tan J, Fishbein M, Chen P-S, et al. IFATS collection: human adipose tissue-derived stem cells induce angiogenesis and nerve sprouting following myocardial infarction, in conjunction with potent preservation of cardiac function. Stem cells (Dayton, Ohio). 2008:27:230-7.

41. Sanganalmath S, Bolli R. Cell therapy for heart failure: a comprehensive overview of experimental and clinical studies, current challenges, and future directions. Circ Res. 2013;113:810-34.

42. Lin M, Liu X, Zheng H, Huang X, Wu Y, Huang A, et al. IGF-1 enhances BMSC viability, migration, and anti-apoptosis in myocardial infarction via secreted frizzled-related protein 2 pathway. Stem Cell Res Ther. 2020;11(1):22

43. Wu Y, Liu X, Zheng H, Zhu H, Mai W, Huang X, et al. Multiple roles of SFRP2 in cardiac development and cardiovascular disease. Int J Biol Sci. 2020;16(5):730-8.

44. Huang A, Huang Y. Role of Sfrps in cardiovascular disease. Therap Adv Chron Dis. 2020:11:2040622320901990.

\section{Publisher's Note}

Springer Nature remains neutral with regard to jurisdictional claims in published maps and institutional affiliations.

- fast, convenient online submission

- thorough peer review by experienced researchers in your field

- rapid publication on acceptance

- support for research data, including large and complex data types

- gold Open Access which fosters wider collaboration and increased citations

- maximum visibility for your research: over $100 \mathrm{M}$ website views per year

At BMC, research is always in progress.

Learn more biomedcentral.com/submissions 